\title{
Akram Khater
}

\section{"GOD HAS CALLED ME TO BE FREE": ALEPPAN NUNS AND THE TRANSFORMATION OF CATHOLICISM IN 18TH-CENTURY}

\section{BILAD AL-SHAM}

This article tells the story of ten Catholic women from Aleppo who, in the early part of the 18th century, sought to establish their own convent in the district of Kisrawan, Lebanon. Their project became the center of a conflict that entangled the devotees, their Jesuit confessors and supporters, the Melkite Church, and the Vatican. Thus, their story is a prism through which to refract the relationships among gender, class, and religion in the Levant. In particular it sheds light on the role of gender in the construction of a "modern" Catholicism. I contend that modernization predates the 19th century in the Middle East and question the opposition of secularism and history versus religion and faith as an artifact of modernity. 